\title{
PENINGKATAN PRESTASI BELAJAR IPA MATERI KALOR MELALUI MODEL GROUP INVESTIGATION PADA SISWA KELAS VII
}

\author{
Winarni ${ }^{1)}$ \\ 1) SMP Negeri 2 Trenggalek \\ winarniaw@gmail.com
}

\begin{abstract}
ABSTRAK: Pembelajaran IPA di SMP menekankan pada pemberian pengalaman belajar secara langsung melalui penggunaan dan pengembangan keterampilan proses dan sikap ilmiah. Penyajian materi dan pngalamaan belajar IPA kepada siswa dilakukan dengan berbagai metode antara lain metode ceramah, Tanya jawab, diskusi, demonstrasi, eskperimen, karya wisata, dan bermain peran. Pembelajaran IPA di SMP meliputi bidang kajian Fisika, Kimia dan Biologi. Penerapan model group investigation dapat meningkatkan prestasi belajar siswa secara signifikan.Hal tersebut dapat diketahui dari kenaikan nilai rata-rata. Nilai rata-rata pada siklus 1 sebesar 71,50 dan nilai pada siklus 2 sebesar 85. Hal ini berarti ada kenaikan nilai rata-rata 13,50. Di samping dari nilai ratarata kenaikan prestasi belajar siswa dapat diketahui dengan melihat prosentase ketuntasan belajar secara klasikal.Pada siklus 1 siswa yang telah tuntas sebanyak 15 anak (49\%) sedang siswa yang belum tuntas sebanyak 17 anak (51\%). Pada siklus 2 siswa yang telah telah tuntas sebanyak 27 anak (85\%) sedang siswa yang belum tuntas sebanyak 5 anak $(15 \%)$. Ketuntasan belajar secara klasikal terjadi peningkatan sebesar $36 \%$.
\end{abstract}

Kata kunci : IPA, Model Group Investigation, Materi Kalor

ABSTRACT: Teaching science in Junior High School has emphasized on giving learning experience directly through the susing and developing process skill and scientific attitude. There are some method in performing scientific learning experience such as expalianing, holsing question and answer, discussion, demonstration, experiment, touring and role playing. Teaching learning scinece here including Physics, chemistry adn Biology. The implementation of group investigation model can improve the students' achievement. It can be known from the increasing of the average value. it has raised from 71,50 in the first cycle becomes 85 in second cycle. It means there is 13,50 increasing. Di samping dari nilai rata-rata kenaikan prestasi belajar siswa dapat diketahui dengan melihat prosentase ketuntasan belajar secara klasikal. After holding fisrt cycle there are 15 students or $49 \%$ who have obtained minimum criteria competence, on the other side there 17 anak (51\%) who cannot obtained it. There is the enhancement after second cycle. 27 (85\%) have obtained minimum criteria and only 5 students (15\%) who has left.

Keywords: IPA, Model Group Investigation, Heat Material.

\section{PENDAHULUAN}

Ilmu Pengetahuan Alam (IPA) berhubungan dengan cara mencari tahu tentang alam secara sistematis, sehingga IPA bukan hanya penguasaan kumpulan pengetahuan yang berupa fakta-fakta, konsep-konsep atau prinsip-prinsip saja tetapi juga suatu proses penemuan. Berdasar pengertian IPA tersebut tampak bahwa dalam kegiatan pembelajaran 
IPA guru harus merangsang siswa untuk aktif melakukan kegiatan misalnya melalui penerapan model pembelajaran yang dapat mengaktifkan siswa melakukan percobaan percobaan dlam memecahnya masalah.Hal itu sesuai dengan tahap perkembangan kognitif siswa.

Pembelajaran merupakan kegiatan yang terjadi dari proses belajar oleh siswa dan mengajar oleh guru dalam memberikan fasilitas. Kegiatan itu saling berkaitan. Kegiatan belajar dan mengajar harus dilaksanakan dengan baik agar dapat membantu meningkatkan mutu proses dan hasil belajar. Pembelajaran IPA di SMP menekankan pada pemberian pengalaman belajar secara langsung melalui penggunaan dan pengembangan keterampilan proses dan sikap ilmiah. Penerapan atau aplikasi dari strategi belajar tidak mengharuskan siswa menghafal fakta-fakta tetapi sebuah stretegi tersebut diharapkan mampu mendorong siswa untuk mengkonstruksikan pengetahuan dibenak mereka sendiri. Guru sebagai motor pembelajaran, harus mampu merencanakan suatu strategi pembelajaran yang memberikan kesempatan kepada anak didik untuk mengembangkan potensi yang ada pada diri siswa melalui kegiatan belajar mengajar di kelas. Potensi tersebut dapat dikembangkan oleh siswa apabila di dalam diri siswa terdapat minat untuk mengetahui sesuatu.

Model pembelajaran yang dapat diterapkan salah satunya adalah Pendekatan Pembelajaran Kooperatif Model Group Investigation.Pembelajaran Kooperatif Model Group Investigation ini dipilih karena selama ini jarang digunakan oleh guru-guru termasuk peneliti dan guru sebagian besar menggunakan model diskusi dan ceramah. Diharapkan dengan menggunakan model Group Investigation guru menjadi kreatif dalam menyampaikan pembelajaran IPA. Model pembelajaran ini bertujuan agar peserta didik lebih tertarik dengan pembelajaran dan materi yang disampaikan lebih mudah tertanam dalam ingatan peserta didik, sehingga hasil belajar peserta didik diharapkan dapat meningkat.

Berdasrkan permasalahan di atas peneliti tertarik untuk mengadakan Penelitian Tindakan Kelas dengan mengambil judul "Peningkatan Prestasi Belajar IPA Materi Kalor dengan Model Group Investigation Pada Siswa Kelas VII Semester I Tahun Pelajaran 2017/2018 di SMP Negeri 2 Trenggalek" dan rumusan masalah penelitian ini adalah Bagaimanan peningkatan prestasi belajar IPA materi Kalor melalui model Group Investigation Pada Siswa Kelas VII Semester I Tahun Pelajaran 2017/2018 di SMP Negeri 2Trenggalek?

Menurut Daniel Zigaro, Group Investigation adalah salah satu bentuk dari Cooperative Learning. Dalam Group Investigation, murid-murid membentuk kelompok yang mempunyai minat sama yng mana didalamnya merencanakan dan mengimplementasikan sebuah investigasi dan menggabungkan penemuannya kedalam sebuah prsetasi kelompok untuk kelas. 
Group Investigation meliputi empat komponen penting antara lain :

a. Investigation (Investigasi)

Merujuk pada fakta yang menjadi focus kelompok dalam proses pencarian informasi mengenai topic yang dipilih.

b. Interaktion ( interaksi )

Tanda dari semua metode pembelajaran kooperatif dibutuhkan bagi siswa untuk mengeksplorasi ide-ide dan saling membantu yang lainnya untuk belajar.

c. Interpretation ( Interpretasi )

Muncul ketika kelompok tersebut menggabungkan dan menguraikan penemuan tiap anggota untuk meningkatkan pemahaman dan kejelasan dari ide-ide

d. Intrinsik Motivation ( Motivasi dari dalam )

Pada siswa distimulasi dengan cara memberikan mereka kebebasan dalam proses investigasi

Menurut Slavin (2009), implementasi Group Investigation dimulai dari enam langkah yang meliputi :

a. Mengidentifikasikan topic dan mengatur murid ke dalam kelompok

1) Para siswa meneliti beberapa sumber, mengusulkan sejumlah topik, dan mengkatagorikan saran-saran

2) Kelas dibagi dalam kelompok kecil 5 - 6 , kemudian bergabung dengan kelompoknya untuk mempelajari topic yang dipilih

3) Komposisi kelompok didasaarkan pada ketertarikan siswa dan harus bersifat heterogen

4) Guru membantu dalam pengumpulan informasi

b. Merencanakan tugas yang akan dipelajari

Siswa merencanakan bersama mengenai apa yang dipelajari, bagaimana mempelajarinya, siapa melakukan apa (pembagian tugas) dan untuk tujuan atau kepentingan apa topic ini diinvestigasi

c. Melaksanakan Investigasi

1) Siswa mengumpulkan informasi, menganalisis data, dan membuat kesimpulan

2) Tiap anggota kelompok berkontribusi untuk usaha-usaha yang dilakukan kelompoknya

3) Siswa saling berdiskusi, mengklarifikasi, mensintesis semua gagasan

d. Menyiapkan Laporan Akhir

1) Anggota kelompok menentukan pesan-pesan esensial dari proyek mereka

2) Anggota kelompok merencanakan apa yang mereka laporkan, dan bagaimana mereka akan membuat preentasi mereka

3) Wakil-wakil kelompok membentuk sebuah panitia acara untuk mengkoordinasikan rencana-rencana presentasi

e. Mempresentasikan Laporan Akhir

1) Presentasi yang dibuat untuk seluruh kelas dalam berbagai macam bentuk

2) Bagian presentasi tersebut harus dapat melibatkan pendengarnya secara aktif

3) Para pendengar tersebut mengevaluasi kejelasan dan penampilan presentasi berdasar kreteria yang telah ditentukan sebelumnya oleh seluruh anggota kelas.

f. Evaluasi 
1) Siswa saling memberikan umpn balik mengenai topic tersebut, mengenai tugas yang telah mereka kerjakan, mengenai keefektifan pengalaman-pengalaman mereka

2) Guru dan murid berkolaborasi dalam mengevaluasi pembelajaran. Penilaian pembelajaran harus mengevaluasi pemikiran paling akhir.

Belajar adalah suatu proses untuk mendapatkan pengetahuan pengalaman sehingga mampu merubah tingkah laku itu menjadi tetap, tidak dapat kembali lagi dengan modifikasi yang sama. Herman Hudoyo (1976). Belajar juga diartikan sebagai perbuatan murid dalam usanya mengubah situasi perkembangan dirinya sendiri dlam bidang material, formal serta fungsional pada umumnya dan bidang intelek pada khususnya. Abu Ahmadi (1978). Sedangkan menurut Sudjana (1989) Belajar merupakan Suatu Proses yang ditandai dengan adanya perubahan pada diri seseorang. Masih banyak lagi pengertian belajar yang bermacam-macam persisnya, namum semuanya mempunyai tujuan pokok yaitu suatu usaha melalui proses untuk mencapai perubahan tinkah laku. Dasimo (2000) mengatakan bahwa belajar adalah menyerap pengalaman, sedang menurut Surachmad (1979) mengatakan belajar adalah mengalami yang berarti menghayati suatu situasi yang actual, penghayatan mana yang menimbulkan respon tertentu dari pihak anak.

Dari penjelasan di atas tentang belajar maka dapat ditegaskan bahwa yang dimaksud belajar adalah berupa nilai-nilai yang berupa bilangan - bilangan yang tertulis dalam buku rapaort sebagai bahan laporan pada orang tua murid. Adapun nilai-nilai tersebut di dapat dari hasil evaluasi setelah proses pembelajaran berlangsung. Hasil evaluasi tersebut setelah dianalisis dapat mengetahui perkembangan motivasi belajar siswa secara perorangan dan dapat juga untuk mengetahui kedudukan siswa dalam pembelajaran IPA.

\section{METODE PENELITIAN}

Penelitian Tindakan Kelas tentang peningkatan prestasi belajar IPA materi Kalor dengan Group investigatioan dilaksanakan dalam sdua siklus. Tiap siklus dilaksanakan dalam empat tahap yaitu :

1. Perncanaan

2. Pelaksanaan

3. Pengamatan

4. Refleksi

Adapun tahapan pelaksanaannya adalah sebagai berikut :

\section{a. Perencanaan}

Pada tahap perencanaan ini yang dilakukan adalah mempersiapkan beberapa perangkat pembelajaran yang meliputi :

1) Mempersiapkan meteri dan bahan ajar ( RPP, LKS, alat dan bahan ajar)

2) Menyiapkan instrument penelitian yang berupa instrument tes evaluasi

3) Mempersiapkan segala kendala yang mungkin timbul pada saat penelitian berlangsung

4) Menentukan tempat dan waktu pelaksanaan 
b. Prosedur Tindakan

Kegiatan yang dilakukan pada tahap ini berupa pelaksanaan pembelajaran dengan menggunakan model Group Investigation, dengan langkah-langkah seperti dipaparkan di bawah ini

1) Guru menyampaikan kompetensi dasar yang akan dicapai

2) Guru mengorientasi siswa pada masalah sesuai dengan motivasi awal

3) Guru membentuk kelompok secara heterogen yang terdiri dari 4-5 siswa

4) Siswa dengan bimbingan guru mempersiapkan investigasi yang berupa percobaan tentang kalor

5) Guru membagikan LKS tentang pengaruh kalor pada suhu benda

6) Guru membimbing siswa mengambil data pengamatan, cara menganalisis hasil pengamatn, menyimpulkan hasil sesuai konsep yang benar

7) Peserta didik mempresentasikan hasil diskusi kelompok

8) Peserta didik mengambil kesimpulan dari kegiatan percobaan dan guru sebagai fasilitator

9) Mengadakan evaluasi

c. Pengamatan

Pengamatan kegiatan pembelajarn dengan model Group Investigation dilaksanakan pada saat pelaksanaan penelitian yaitu pada saat proses pembelajaran berlangsung. Pengamatan dilakukan oleh peneliti. Dalam rangka menyusun catatan lapangan.Catatan lapangan disusun untuk menyususn refleksi pembelajaran. Sedangkan yang diamati adalah proses pembelajaran bagaimana peserta dalam melaksanakan investigasi yang meliputi menggunkan alat merangkai alat cara memperoleh data keaktifan mendiskusikan data yang diperoleh selam pembelajaran berlangsung

d. Refleksi

Pada tahap ini merupaan tahap memproses data yang telah didapat saat dilakukan pengamatan tindakan selanjutnya.

a. Menganalisis data yang terkumpul

b. Mengidentifikasi dan mengelompokkan masalah yang timbul

c. Mengumpulkan hasil penelitian jika masih ada masalah pada siklu 1 maka masalah tersebut digunalan sebagai dasar untuk menentukan tindakan pada sikus berikutnya

d. Mencari alternative pemecahan pada siklus berikutnya

Bila dari kegiatan refleksi ini belum mencapai indicator yang ditetapka yaitu $85 \%$ peserta didik telah tuntas atau memperoleh nilai sama dengan atau lebih dari Predikat B yaitu nilai 77 , maka penelitian dilanjutkan siklus 2.

\section{Subyek Penelitian}

Dalam Penelitian Tindakan Kelas ini sebagai subyek penelitian adalah siswa kelas VII semester 2 Tahun Pelajaran 2016/2017 SMP Negeri 2 Trenggalek dengan alamat jalan Mastrip Trenggalek dengan jumlah siswa 25 orang.Instrument Penelitian Penelitian ini secara garis besar menggunakan instrument tes berbentuk pilihan ganda dengan 
jumlah soal 10.Soal instrument tes dilaksanakan setiap akhir pembelajaran sebanyak 2 kali. Instrument disusun diluar jam pelajaran.

\section{Teknik Pemgumpulan Data}

Teknik pengumpulan data dalam Penelitian Tindakan Kelas ini adalah melalui tes hasil belajar. Penilaian dilaksaanakan setelah berlangsungnya proses pembelajaran, data nilai dikumpulkan dengan cara meliai hasil belajar kalor peserta didik kelas VII semester 1 Tahun pelajaran 2017/2018

\section{Teknik Analisis data}

Data yang diperoleh dari hasil tes tulis di analisis untuk menentukan :

1. Nilai siswa

2. Rata-rata nilai

3. Prosentase ketuntasan evaluasi siswa

a. Nilai siswa diolah dengan cara menjumlahkan nilai skor tiap soal. Skor untuk tiap soal dengan jumlah soal 10 sehingga nilai maksimum 100. Adapun rumus untuk menghitung nilai tiap siswa adalah :

$$
\text { Nilai }=\frac{\text { Jumlah skor }}{\text { Nilai Maksimum }}
$$

b. Nilai Rata - Rata

Nilai rata-rata diperoleh dengan cara menjumlahkan nilai seluruh siswa selanjutnya dibagi dengan jumlah seluruh siswa. Adapun rumus untuk menghitun rata-rata nilai siswa adalah sebagai berikut :

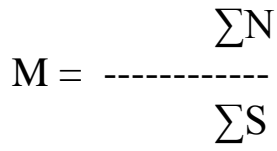

Keterangan :

$\mathrm{M}=$ nilai rata-rata

$\sum \mathrm{N}=$ jumlah nilai seluruh siswa

$\sum \mathrm{S}=$ jumlah siswa

c. Prosentase Ketuntasan

Prosentase ketuntasan diperoleh dengan cara menjumlahkan nilai siswa yang telah tuntas dibagi dengan jumlah seluruh siswa, kemudian dikalikan dengan $100 \%$ adalah :

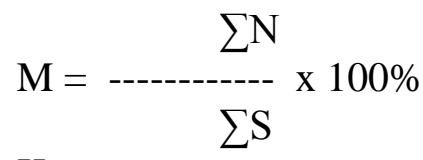

Keterangan :

$\mathrm{P} \quad=$ prosentase ketuntasan

$\sum \mathrm{N}=$ jumlah nilai seluruh siswa

$\sum \mathrm{S}=$ jumlah siswa 
Ketuntasan belajar IPA di SMP Negeri 2 Trenggalek dikatakan tuntas jika $\geq$ $85 \%$ siswa mendapatkan nilai $\geq 77$ (berdasarkan ketentuan yang telah ditetapkan di SMP Negeri 2 Trenggalek.

\section{HASIL DAN PEMBAHASAN}

\section{Hasil Penelitian}

1. Prasiklus

a. Pelaksanaan pembelajaran IPA

Pembelajaran IPA yang berlangsung di kelas VII SMP Negeri 2 Trenggalek menggunakan metode ceramah dan Tanya jawab. Penggunaan metode tersebut berdampak pada prestasi siswa yang relatif rendah (pasif. Hal ini dibuktikan dengan kegiatan siswa yang hanya duduk diam memperhatikan meteri yang disampaiakan, bahkan ada juga yang tidak memperhatikan sama sekali paparan materi yang disampaiakan oleh guru. Guru juga sudah memberikan soal latihan dibuku yang harus dikerjakan oleh siswa secara individu, serta soal-soal evaluasi setelah selesai mempelajari materi tersebut.

Siswa kesulitan mengingat kembali materi yang sudah disampaikan oleh guru.Suasana pembelajaran yang dirasakan dan dialami siswa kurang menyenangkan.Studi pendahuluan tersebut menghasilkan masalah-masalah proses dan hasil pemebelajaran IPA di kelas VII semester 2 SMP Negeri 2 Trenggalek. Dalam proses pembelajaran peneliti merasa adanya masalah dalam hal penerapan strategi pembelajaran IPA yang kurang tepat, suasana pembelajaran yang kurang menyenangkan, aktivitas belajar siswa yang rendah, dan rendahnya prestasi belajar siswa pada mata pelajaran IPA.

b. Prestasi Belajar IPA Siswa Kleas VII

Prestasi belajar kelas VII SMP Negeri 2 Trenggalek masih kurang. Hal ini terbukti dari banyaknya siswa yang nilainya dibawah Kriteria Ketuntasan Minimal (KKM), KKM Mata Pelajaran IPA adalah 75

Analisis prestasi belajar IPA siswa Kelas VII SMP Negeri 2 Trenggalek nilai ratarata 64,12 dengan prosesntase ketuntasan 50\% Nilai rata-rata masih jauh dari KKM yang ditetapkan yaitu 77 (Predikat B) dan ketuntasan klasikal belum mencapai $85 \%$.

2. Paparan Siklus 1

a. Perencanaan

Dalam perencanaan tindakan ini dipersiapkan kebutuan-kebutuhan sesuai dengan penelitian yang akan dilakukkan berkenaan dengan pembelajaran yang di terapkan

1) Membuat Rencana Pelaksanaan Pembelajaran (RPP) dengan mengacu pada tindakan yang diterapkan dalam PTK yaitu dengan model pembelajaran Group Investigation

2) Membuat Lembar Kerja Siswa (LKS)

3) Membuat instrument yang akan digunakan dalam penelitian, tes tulis pilihan ganda sebanyak 10 nomor.

b. Pelaksanaan Tindakan 
Pelaksanaan kegiatan belajar mengajar untuk siklus 1 dilaksanakan di kelas VII SMP Negeri 2 Trenggalek dengan jumlah siswa 25 siswa.Penelitian ini dilaksanakan pada tanggal 9 September dan 10 September 2017dengan alokasi waktu 2 JP x 40 menit.Dalam hal ini peneliti bertindak sebagai pengajar dibantu oleh seorang teman sejawat sebagai kolaborator untuk melakukan pengamatan selama kegiatan pembelajaran berlangsung. Adapun proses belajar mengajar mengacu pada rencana pembelajaran yang telah dipersiapkan. Pengamatan dilaksanakan bersamaan dengan pelaksanaan belajar mengajar.

Pada kegiatan pembelajaran, guru membagi siswa kedalam kelompok kecil. Setiap kelompok terdiri dari 4 - 5 siswa. Pada akhir proses belajar mengajar siswa diberi tes dengan tujuan untuk mengetahui prestasi belajar IPA siswa menggunakan model Group Investigation. Data prestasi belajar siswa materi kalor diperoleh nilai dapat dilihat pada tabel berikut

Tabel 1. Hasil Tes Siklus 1

\begin{tabular}{|c|c|c|c|c|c|}
\hline No & Nilai & Frekwensi & N X F & Prosentasi & Keterangan \\
\hline 1 & 100 & 2 & 200 & 8,00 & Tuntas \\
\hline 2 & 90 & 2 & 180 & 8,00 & Tuntas \\
\hline 3 & 80 & 7 & 560 & 28,00 & Tuntas \\
\hline 5 & 70 & 7 & 490 & 28,00 & Tidak Tuntas \\
\hline 6 & 60 & 7 & 420 & 28,00 & Tidak Tuntas \\
\hline \multicolumn{2}{|c|}{ Jumlah } & 25 & 1850 & 100 & \\
\hline \multicolumn{3}{|c|}{ Rata - rata } & 74 & & \\
\hline
\end{tabular}

Dari tabel 1 dapat dijelaskan bahwa dengan menerapkan model Group Investigation diperoleh nilai tes tertinggi 100 dan terendah 60 . Siswa yang mendapat nilai 100 sebanyak 2 anak (8\%), siswa yang mendapat 90 sebanyak 2 anak (8\%), siswa yang mendapat 80 sebanyak 7 siswa (28\%), siswa yang mendapat 70 sebanyak 7 anak (28\%), siswa yang mendapat 60 sebanyak 7 anak (28). Nilai rata - rata IPA 74 dan ketuntasan belajar yang dicapai siswa adalah .Prestasi tersebut menunjukkan bahwa pada siklus 1 secara klasikan, siswa belum tunras belajar, karena siswa memperoleh nilai rata-rata 74 , belum mencapai KKM atau $\geq 75$. Sedangkan persentase ketuntasan klasikal sebesar 44 $\%$ berarti belum mencapai indicator sebesar $85 \%$.

Ada beberapa faktor penyebab ketidaktercapaian indicator penelitian ini diantaranya :1) pembentukan kelompok yang kurang heterogen, anak-anak yang pandai cenderung berkumpul dalam satu kelompok; 2) benyak siswa yang masih ramai dalam kelompoknya; 3) anak yang pandai tapi pendiam belum berani menyampaikan gagasan untuk kelas. Berdasarkan data rata-rata nilai dan prosentase ketuntasan mklasikal indikator penelitian belum tercapai. Oleh karena itu penelitian ini dilanjutkan ke siklus ke 2

Tabel 2 Hasil Tes Siklus 2

\begin{tabular}{|c|c|c|c|c|c|}
\hline No & Nilai & Frekwensi & N X F & Prosentase & Keterangan \\
\hline 1 & 100 & 5 & 500 & 20,00 & Tuntas \\
\hline 2 & 90 & 10 & 900 & 40,00 & Tuntas \\
\hline 3 & 80 & 8 & 640 & 32,00 & Tuntas \\
\hline
\end{tabular}




\begin{tabular}{|l|c|c|c|c|c|}
\hline 5 & 70 & 2 & 140 & 8,00 & Tidak Tuntas \\
\hline \multicolumn{2}{|c|}{ Jumlah } & 25 & 2180 & 100 & \\
\hline \multicolumn{2}{|c|}{ Rata - rata } & 87,20 & & \\
\hline
\end{tabular}

Dari tabel 2 dapat dijelaskan bahwa dengan menerapkan model Group Investigation diperoleh nilai tes tertinggi 100 dan terendah 70. Siswa yang mendapat nilai 100 sebanyak 5 anak (20\%), siswa yang mendapat 90 sebanyak 10 anak (40\%), siswa yang mendapat 80 sebanyak 8 siswa (32\%), siswa yang mendapat 70 sebanyak 2 anak ( 8 $\%)$,. Nilai rata - rata IPA 87,2 dan ketuntasan belajar yang dicapai siswa adalah $92 \%$. Prestasi tersebut menunjukkan bahwa pada siklus 2 secara klasika, siswa sudah tunras belajar, karena siswa memperoleh nilai rata-rata 87,20, berarti sudah mencapai KKM atau $\geq 75$.

\section{Pembahasan}

Berdasarkan hasil penelitian yang telah dilaksanakan sebanyak 2 siklus diperoleh data seperti berikut ini.Model Group Investigation dapat meningkatkan prestasi belajar IPA materi kalor. Hasil penelitian siklus 1 dan siklus 2 dapat dipaparkan dalam tabel 3 berikut ini :

Tabel 3. Hasil Siklus 1 dan Siklus 2

\begin{tabular}{|c|c|c|c|c|c|c|c|c|}
\hline \multirow{2}{*}{ No } & \multirow{2}{*}{ Nilai } & \multicolumn{3}{|c|}{ Siklus 1} & \multicolumn{3}{|c|}{ Siklus 2} & \multirow{2}{*}{ Keterangan } \\
\hline & & $\mathrm{F}$ & $\mathrm{NXF}$ & $\%$ & $\mathrm{~F}$ & NXF & $\%$ & \\
\hline 1 & 100 & 2 & 200 & 8,00 & 5 & 500 & 20,00 & Tuntas \\
\hline 2 & 90 & 2 & 180 & 8,00 & 10 & 900 & 40,00 & Tuntas \\
\hline 3 & 80 & 7 & 560 & 28,00 & 8 & 640 & 32,00 & Tuntas \\
\hline 4 & 70 & 7 & 490 & 28,00 & 2 & 140 & 8,00 & Tidak Tuntas \\
\hline 5 & 60 & 7 & 420 & 28,00 & 0 & 0 & 0 & Tidak Tuntas \\
\hline \multicolumn{2}{|c|}{ Jumlah } & 25 & 1850 & 100 & 25 & 2180 & 100 & \\
\hline \multicolumn{3}{|c|}{ Rata - rata } & 74,00 & & & 87,20 & & \\
\hline
\end{tabular}

Dari tabel 3 dapat dijelaskan bahwa dengan menerapkan model Group Investigation diperoleh nilai ter tertinggi siklus 1 adalah 100 dengan jumlah siswa 2 anak ((8\%) dan siklus 2 adalah 100 dengan jumlah siswa 5 anak (20\%), sedangkan nilai terendah pada siklus 1 adalah 60 dan pada siklus 2 adalah 70. Siswa yang mendapat nilai 90 pada siklus 1 sebanyak 2 anak (8\%); pada siklus 2 sebanyak 10 anak (40\%). Siswa yang mendapatkan nilai 80 pada siklus 1 sebanyak 7 anak ( $28 \%$ ), pada siklus 2 sebanyak 8 anak (32\%). Siswa yang mendapat nilai 70 pada siklus 1 sebanyak 7 anak (28\%), sedang pada siklus 2 sebanyak 2 anak (8\%). Siswa yang mendapatkan nilai 60 pada siklus 1 sebanyak 7 anak (28\%), pada siklus 2 tidak ada.

Selanjutnya untuk mengetahui kenaikan prestasi belajar IPA materi kalor dengan model Group Investigation dapat dilihat pada diagram 1. berikut ini 


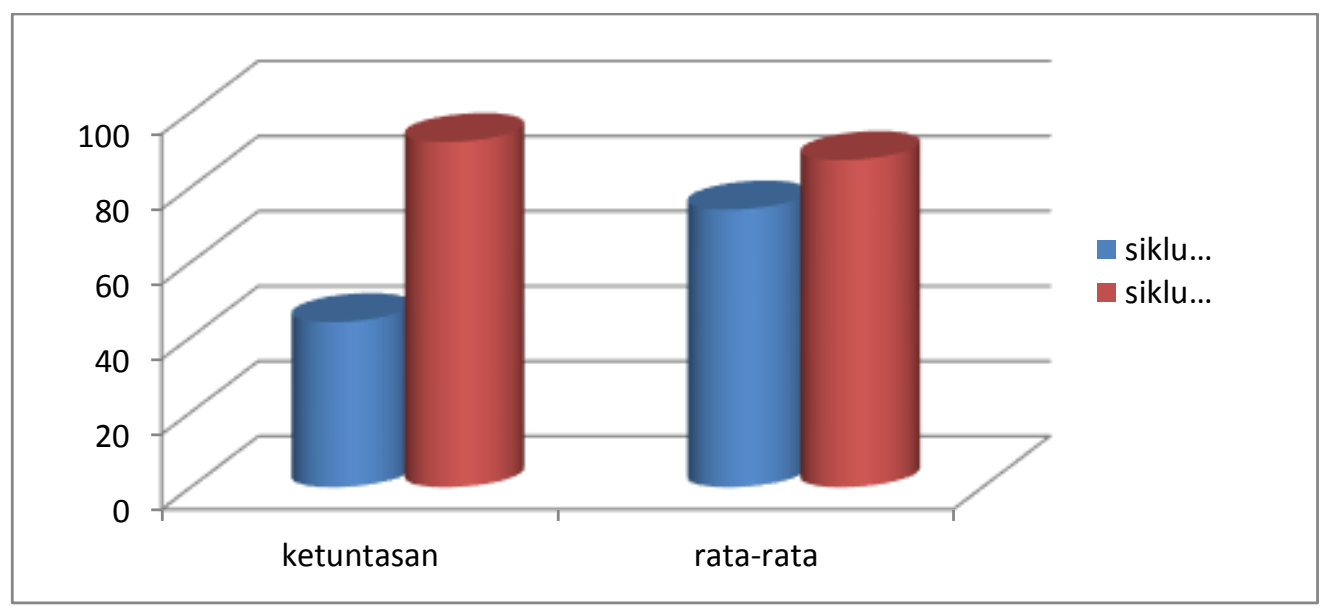

Gambar 1. Perbandingan Rata-rata dan

Ketuntasan Prestasi Siklus 1 dan Siklus 2

Berdasarkan gambar 1 dijelaskan bahwa nilai rata-rata pada siklus 1 sebesar 74,00 sedangkan nilai rata-rata pada siklus 2 adalah 87,20. Hal ini berarti terjadi kenaikan nilai rata-rata 13,20. Disamping itu dapat dijelaskan pula bahwa prosentas ketuntasan belajar secara klasikal pada siklus 1 adalah 44\%, sedangkan pada siklus 2 adalah 92\%.Hal ini berarti bahwa terjadi kenaikan prosentase ketuntasan belajar klasikal sebesar $48 \%$. Untuk memperjelas terjadinya peningkatan hasil belajar IPA dengan materi kalor pada siklus 1 dan siklus 2 dapat ditampilkan dalam diagram berikut ini.

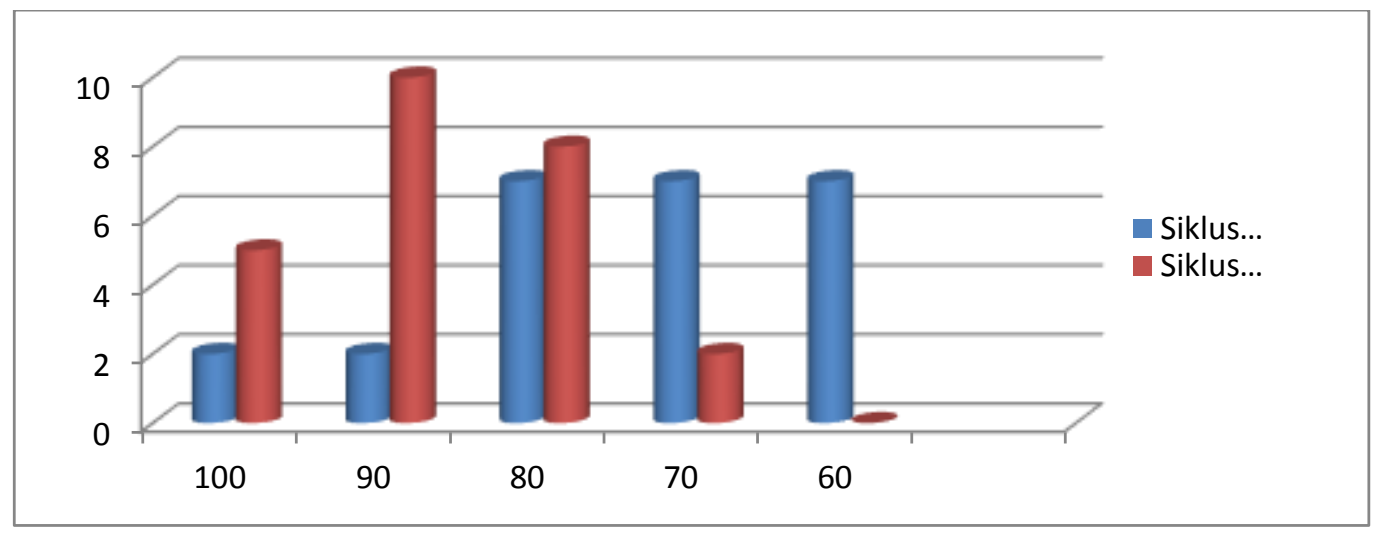

Gambar 2. Perbandingan Nilai Pada Siklus 1 dan Siklus 2

Berdasarkan gambar 2 diketahui bahwa nilai terendah adalah 60 pada siklus 1 menjadi 70 di siklus 2. Nili tertinggi tetap 100 tetapi jumlah siswa yang mendapatkan adalah 2 anak di siklus 1 dan menjadi 5 disiklus 2 . Jumlah perolehan nilai terbanyak pada 
silus 1 adalah 80 dengan jumlah siswa 7 anak, sedangkan perolehan nilai terbanyak pada siklus 2 adalah 90 dengan jumlah siswa 10 anak. Dari data tersebut menunjukkan adanya peningkatan nilai dari siklus 1 ke siklus 2.

Peningkatan ketuntasan belajar secara klasikal dapat diketahui dari membandingkan prosentase siswa yang telah tuntas belajar di siklus 1 dengan siklus 2 . Perbandingan ketuntasan belajar dapat dilihat pada tabel berikut .

Tabel 4. Perbandingan Ketuntasan Belajar Siklus 1 dan Siklus 2

\begin{tabular}{|c|c|c|c|c|c|}
\hline \multirow{2}{*}{ No } & \multirow{2}{*}{ Keterangan } & \multicolumn{2}{|c|}{ Siklus 1 } & \multicolumn{2}{c|}{ Siklus 2 } \\
\cline { 3 - 6 } & & Jumlah siswa & Prosentase (\%) & Jumlah siswa & Prosentase (\%) \\
\hline 1 & Tuntas & 11 & 44 & 23 & 92 \\
\hline 2 & Belum Tuntas & 14 & 56 & 2 & 8 \\
\hline
\end{tabular}

Ketuntasan hasil belajar ditentukan dengan cara membandingkan ynilai yang diperoleh siswa dengan KKM mata pelajaran IPA sebesar 75. Pada silus 1 siswa yang telah tuntas 11 anak (44\%) sedangkan siswa yang belum tuntas 14 anak (54\%). P ada siklus 2 siswa yang telah tuntas sebanyak 23 anak (92\%) dan siswa yang belum tuntas sebanyak 2 anak (8\%).Berdasarkan data tersebut berarti bahwa ketuntasan belajar secara klasikan telah mencapai indikator penelitian, sedangkan 2 anak yang beum tuntas pada siklus 2 diadakan remidi secara pribadi.

\section{KESIMPULAN DAN SARAN}

\section{Kesimpulan}

Prestai belajar siswa kelas VII Semester 1 Tahun Pelajaran 2017/2018di SMP Negeri 2 Trenggalek mengalami peningkatan.Hal tersebut dapat diketahui dari kenaikan nilai rata-rata. Nilai rata-rata pada siklus 1 sebesar 74 dan pada siklus 2 sebesar 87,2 hal ini berarti terjadi peningkatan nilai rata-rata 13,2 Disamping nilai rata-rata kenaikan prestasi belajar siswa dapat dilihat dari prosentase ketuntasan belajar secara klasikal. Pada siklus 1 siswa yang telah tuntas sebanyak 11 anak (44\%) sedangkan siswa yang belum tuntas sebanyak 14 anak (56\%). Pada siklus 2 siswa yang telah tuntas sebanyak 23 anak (92\%) sedangkan siswa yang belum tuntas sebanyak 2 anak (8\%). Ketuntasan belajar secara klasikal terjadi peningkatan sebesar $48 \%$. Berdasarkan kenaikan nilai rata-rata dan prosentase ketuntasan klasikal dapat disimpulkan bahwa model Group Investigation dapat meningkatkan prestasi belajar IPA materi kalor pada siswa kelas VII semester 1 Tahun pelajaran 2017/2018 di SMP Negeri 2 Trenggalek

\section{Saran}

Berdasarkan hasil Penelitian Tindakan Kelas ini peneliti memberikan saran sebagai berikut : 
1. Guru hendaknya dapat memilih model pembelajaran yang sesuai dengan karakteristik mata pelajaran IPA berdasarkan materi pelajaran dan karakter siswa.

2. Guru hendaknya mampu memilih media pembelajaran yang sesuai dengan hakikat IPA dengan mengadakan percobaan atau praktek untuk memperoleh pengetahuan.

3. Guru hendaknya mengubah paradikma pembelajaran dari teacher centre menjadi student centre.

\section{DAFTAR RUJUKAN}

Arikunto, S, 2006 Penelitian Tindakan Kelas, Jakarta; PT Bumi Aksara

Arikunto, S, Suhardjono \& Supardi, 2008 Penelitian Tindakan Kelas, Jakarta; Bumi Aksara

Demar Hamalik, Metodologi Belajar dan Kesulitan-Kesulitan Belajar, Tarsito, Bandung, 1980

Kistona, AR, Classroom Action Research, makalah Penelitian Wakasek Kurikulum SD se Jawa Timur, di BPG Surabaya, tahun 2002.

Lie, Anita. 2008. Cooperative Learning. Jakarta : Grasindo.

Poerwodarminto, WJS. Kamus Bahasa Indonesia, Balai Pustaka, Jakarta, 1984

Richard, A. 2008. Belajar Untuk Mengajar. Yogyakarta: Pustaka Belajar.

Sutrisno Hadi, Metodologi Research, Fakultas Psikologi, Universitas Gajah Mada Yogyakarta, 1986.

Suharsimi Arikunto, Prosedur Penelitian, Bina Aksara Jakarta.

Winarno Surakhmad, Dasar dan Teknik Research Pengantar Metodologi Ilmu, Tarsito, Bandung, 1980. 